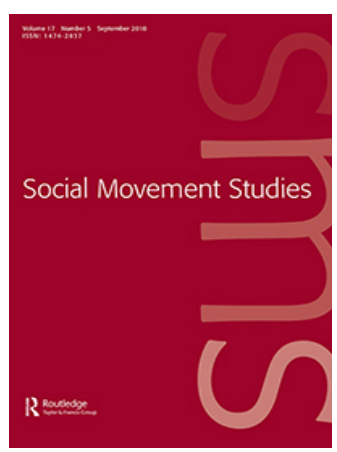

Social Movement Studies

\title{
Between organization and spontaneity of protests: the 2010-2011 Tunisian and Egyptian uprisings
}

\section{Katia Pilati, Giuseppe Acconcia, David Leone Suber \& Henda Chennaoui}

To cite this article: Katia Pilati, Giuseppe Acconcia, David Leone Suber \& Henda Chennaoui (2019): Between organization and spontaneity of protests: the 2010-2011 Tunisian and Egyptian uprisings, Social Movement Studies

To link to this article: https://doi.org/10.1080/14742837.2019.1567322

View supplementary material $\Longleftarrow$

Published online: 22 Jan 2019.

Submit your article to this journal $₫$

View Crossmark data \lceil 


\title{
Between organization and spontaneity of protests: the 2010-2011 Tunisian and Egyptian uprisings
}

\author{
Katia Pilati (iD) ${ }^{a}$, Giuseppe Acconciab ${ }^{b}$ David Leone Suber ${ }^{c, d}$ and Henda Chennaoui ${ }^{e, f}$ \\ ${ }^{\mathrm{a} D e p a r t m e n t}$ of Sociology and Social Research, University of Trento, Trento, Italy; ${ }^{\mathrm{b}}$ Department of Political \\ Science, Law, and International Studies, University of Padua, Padua, Italy; 'Political Science Department, \\ Tübingen University, Tübingen, Germany; ${ }^{\mathrm{d} T h e}$ American University of Cairo, Cairo, IL, Egypt; ${ }^{\text {NNawaat, }}$ \\ Tunis, Tunisia; fSociology Department, Ibn Charaf University, Tunis, Tunisia (MA)
}

\begin{abstract}
This paper investigates the role of social groups in mobilizing resources for protests in repressive contexts. In particular, it examines the impact of organizations and informal groups on individual engagement in the protests developed in 2010 in Tunisia and in 2011 in Egypt. The empirical analysis draws on the following data sources: the second wave of the Arab Barometer (2010-2011), two focus groups in Egypt conducted between 2011 and 2015 with members of trade unions and of Popular Committees who had participated in the 2011 protests in Egypt, eight semi-structured interviews conducted in 2017 to workers in Tunisia who had engaged in the 2010-2011 protests, and interviews conducted in January and February 2011 to 100 women in Tunisia within a study tackling police violence against women during the Tunisian uprisings.

Findings show that both in Egypt and Tunisia protests were neither spontaneous nor fully organized as formal organizations and informal and spontaneous groups strictly interconnected in sustaining protests. In Egypt, established Islamic charity networks provided the structural basis for Popular Committees to engage in the 2011 protests and the initially spontaneous workers' groups, institutionalized through the legalization of EFITU, were crucial for national wide protests occurred throughout 2011. In Tunisia, the major trade union UGTT was essential for mobilizing workers in the initial stages of protests but was backed by informal and spontaneous groups of workers during the process of protest diffusion.

Results remark that the 2010-2011 Tunisian and Egyptian uprisings were therefore well-grounded on intermediate mobilizing structures capable to survive in the interstices of an authoritarian context. Findings suggest to consider that, in repressive context, spontaneous groups and more established and formal
\end{abstract}

\section{ARTICLE HISTORY}

Received 7 February 2018

Accepted 3 January 2019

\section{KEYWORDS}

Protests; Arab uprising; Egypt; Tunisia; organizations; informal groups; social movements

CONTACT Katia Pilati katia.pilati@unitn.it Department of Sociology and Social Research, University of Trento, Via Verdi 26, Trento 38122, Italy

Author Links Katia Pilati https://webapps.unitn.it/du/it/Persona/PER0003868/Curriculum ORCID orcid.org/0000-0002-92346230Giuseppe Acconcia https://persone.csia.unipd.it/persone/spgi/ass/9BED9BA10870750C5116C7A6818E14E4ORCID https://orcid.org/0000-0001-5941-8346; Profiles: Twitter @stradedellest David Leone Suber https://brushandbow.comHenda Chennaoui https://nawaat.org/portail/author/handoud/Profiles: Twitter: @hendoudhenda Facebook: Henda Chennaoui + Supplemental data for this article can be accessed here. 
organizations continuously switch from one form to another, overlap, and transform themselves faster than they would do in democratic contexts.

Protests erupted in December 2010 in Tunisia and in January 2011 in Egypt were the product of large cross-class coalitions in which young people and students joined middle-class professionals, government employees, workers, housewives and the unemployed. Most scholars agree on the fact that these protests were spontaneous, often relying on informal ties among friends or neighbors, sustained by online ties. Scholars also argue that protests lacked coordination by major social movement organizations (SMOs). However, not all evidence is consistent with such claims. In the case of Tunisia, the local chapters of the major trade union, Union Générale Tunisienne du Travail (UGTT), were crucial for the eruption of protests.

Drawing on social movement insights on the role of intermediate structures of resources mobilization and on area studies focused on Egypt and Tunisia, this article aims to investigate the role of various types of social groups, namely, informal and spontaneous ones like peer groups and more formal ones like organizations, for protest engagement. Our aim is to examine the so-called Arab Spring in Tunisia and Egypt and to answer the following research questions: Which types of groups were useful to mobilize individuals to join the protests erupted in December 2010 in Tunisia and in January 2011 in Egypt? What were the degree of spontaneity and the role of informal ties compared to the role of more structured organizations during the Arab uprisings?

The empirical analysis draws on various sources of data. First, we use the second wave of the Arab Barometer (2010-2011) which includes detailed information on the specific participation by individuals in anti-regime protests in Tunisia and in Egypt. Using this dataset we examine the effect of individual involvement in various types of organizations, and of informal ties on the protests erupted in December 2010 in Tunisia and in January 2011 in Egypt. Second, we examine data obtained from two focus groups in Egypt. One focus group addressed seven members of Popular Committees and the second one involved nine members of trade unions. The focus groups were, respectively, conducted in Mahalla al-Kubra (Nile Delta) and Sayeda Zeinab (Cairo) between 2011 and 2015. ${ }^{1}$ For Tunisia, the empirical analysis relies on eight semistructured interviews conducted in 2017 to private sector workers and unemployed youth in the neighborhoods of Yasminette, Medinat Jedida, and Ben Arous, in Greater Tunis. In addition, the Tunisian analysis draws on extracts from 100 interviews to women, undertaken between January and February 2011 in Kasserine (Zouhour and Nour) and Thala (Chennaoui \& Baraket, 2011). ${ }^{2}$

The main contribution of this paper lies in attempting a better understanding of the contexts of mobilization under repressive conditions, shedding light on the mobilizing role of different social groups for protests in repressive contexts. ${ }^{3}$ 


\section{Contexts of mobilization under repressive conditions}

Numerous hypotheses have been put forward to explain the development of protests in repressive contexts. Many studies have adopted a state-centered or political-process approach which treats repression as a crucial dimension accounting for shifting political opportunities for collective actions (Almeida, 2003; Beck, 2014; Brockett, 1991; Davenport, Hank, \& Mueller, 2005; Goldstone \& Tilly, 2001; Tilly, 1978). These studies have advanced a direct relationship between repression and protest although no consistent evidence on the hypothesis linking repression and protests has been provided (Carey, 2009). In an endeavor better to specify the effects of repression on protest mobilization, scholars have suggested that the impact of repression on protests is conditional on intermediate mobilizing structures, that is, on the social groups which can operate in repressive contexts and which are able to mobilize the necessary resources for collective action (Trejo, 2012, p. 84; Kadivar, 2013). On the one hand, some scholars have argued that organizations - formal groups implying decisions about membership criteria, rule, hierarchy, monitoring of behaviors and allocation of incentives and sanctions (Ahrne \& Brunsson, 2011, p. 86) - play a relevant role not only in democratic contexts for which most evidence has been provided, so far, but also under repressive conditions (Trejo, 2012). On the other, scholars have argued that informal groups - with no stable structure, where members' roles, positions, and behaviors are not defined by fixed and rules as in organizations, and whose actions often concern daily practices and individual experience (cf. Melucci, 1996) - are more crucial in such contexts (Bayat, 2010; Pfaff, 1996). In the following paragraphs, we discuss in more detail both the roles of organizations and of informal groups in shaping protests in repressive contexts.

\section{The role of organizations}

In repressive contexts, the free space available for oppositional social groups is highly restricted (Clark, 2004, p. 170; Moghadam \& Gheytanchi, 2010; Pilati, 2011, 2016; Tchaïcha \& Arfaoui, 2017; Trejo, 2012; Wiktorowicz, 2004). Opposition parties are outlawed, independent social organizations are severely regulated; citizens are often organized into government-controlled associations linked to the ruling party; universities, newspapers, organizations such as workers and farmers' associations, and women and youth rights' groups are often the objects of frequent attacks by ruling governments. SMOs, the most crucial mobilizing structures for collective actions in democratic countries (Davis, McAdam, Scott, \& Zald, 2005; Diani, 2015; McCarthy \& Zald, 1977), need to adapt to a constraining environment limiting their usual activities. Under authoritarian rules, SMOs have indeed to adjust and innovate their repertoire of action, can radicalize their activities, moderate the repertoire, or transnationalize it (Pilati, 2016). Many organizations operating in repressive contexts, rather than being active in explicit political authority-oriented activities focus on service-delivery and client-oriented actions (Kriesi, 1996) which are not perceived as threatening by political authorities. Organizations focusing on apolitical activities - charities, sport organizations, football fans groups, literacy clubs, or religious organizations - often represent the only free space accessible to individuals in repressive contexts and can become 
places where broader processes of political socialization take place (cf. Bayat, 2010; Clark, 2004; Dorsey, 2012; Tekeli, 1995). A few mechanisms have been highlighted by social movement scholars to account for the mobilizing role of these organizations. Service-delivery organizations indeed facilitate social and recreational activities, which are places where people discuss and reinforce their sociability networks. In addition, as most voluntary organizations in Europe and in the USA (Verba, Schlozman, \& Brady, 1995), they convey resources such as leadership, skills related to the management of collective events, group coordination, and information channels. Next to resource-based mechanisms, these organizations can also provide a rationale for opinions and actions, and can define members' collective identities. In other words, they can provide a 'cultural toolkit' of collectively held meanings and symbols used as a collective action frame (McVeigh \& Sikkink, 2001, p. 1429). When experiencing repressive measures, apolitical organizations can, therefore, become places for sustaining the creation and intensification of political consciousness and narratives of cultures of resistance. Studies have also shown that football fans groups provide a venue to release anger and frustration, becoming a key institution capable of confronting security force-dominated repressive regimes (Dorsey, 2012).

As to the role of organizations in Egypt and Tunisia, there is quite a few evidence on their role before the 2010-2011 protests. The 2008 protests in the textile industry of Mahalla El-Kubra in Egypt had indeed been characterized by wildcat strikes, not supported by the official trade union, the Egyptian Federation of Trade Unions (EFTU), the only recognized trade union in Egypt during Mubarak's regime. However, the local chapters of the major trade union in Tunisia, UGTT, have been central during the local protested occurred in 2008 in the Gafsa mining basin (Beinin \& Vairel, 2011).

Social Islamic organizations and assistance networks, da'wa, have, in turn, enabled individuals to become active participants in political life in Egypt (Wickham, 2002). By promoting new values, identities, and commitments, the Islamists had created new motivations for political action. In Egypt, the graduates' embrace of an ideology throughout the nineties was indeed based on framing activism as a 'moral obligation' demanding self-sacrifice and unflinching commitment to the cause of religious transformation (Wickham, 2002, pp. 148-151). Furthermore, in Egypt, organizations such as Kifaya (Enough!), a network striving for reforms and change - including organizations such as Journalists for Change, Doctors for Change, Youth for Change, Workers for Change, Artists for Change - and the April 6th Youth Movement (A6YM) were also active prior and during the Arab Spring (Beinin \& Vairel, 2011). Public gatherings organized from December 2004 to September 2005 in Egypt by Kifaya were all possible thanks to the strategy to self-limit the scope of mobilization both in the number of people participating in the organized demonstrations, never exceeding a thousand people, and in the choice of its location, mobilizing in downtown Cairo rather than in densely populated areas. This had enabled Kifaya to repeatedly denounce domestic issues, for instance, during public gatherings against President Husni Mubarak's attempts to enact hereditary succession (Beinin \& Vairel, 2011, p. 185; Duboc, 2011, p. 61, p. 32).

In 2005 some members of the Muslim Brotherhood in Alexandria and supporters of the Revolutionary Socialists also formed the National Alliance for Change and Unions 
within the universities. The same activists were later on among those who took part in anti-police riots that broke out after the murder of the young activist Khaled Said in Alexandria in 2010 by a police officer.

In Tunisia, the UGTT was, and currently is, the strongest trade union force in the country, bringing together the middle class with a high concentration in the public sector. One of the strengths of the UGTT has been its political role. Indeed, since independence in 1956, two currents coexist within it: one, controlled by the regime, embodied by what is commonly called the 'union bureaucracy'; the other one more inclined to resistance practices - playing a decisive role in the organization of strikes, rallies, and demonstrations - controlling certain federations such as those of education or posts and telecommunications, as well as some regional or local unions. With such characteristics, many social movement groups have found support from the federations and sections of the UGTT.

Next to UGTT, despite the political repression under both Ben Ali and Bourguiba regimes the Tunisian Association of Democratic Women (ATFD) has also played an important role in the opposition to the regime throughout the nineties and the new millennium. Legalized in 1989, the ATFD focused its struggle against Ben Ali's state feminism, against Islamism and rising conservatism (Debuysere, 2018, 9). While ATFD was concerned with both redistribution and issues related to recognition, the former implied significant support to several protests which were sometimes undertaken in cooperation with UGTT, like those in Gafsa in 2008, despite women had been largely underrepresented in the UGTT leadership roles (Debuysere, 2018, p. 10). This provided great legitimacy to ATFD after 14 January 2011 and, despite its conflicts with the Islamists, enabled the organization to play an important role in the subsequent political transition.

Following these studies and evidence in Tunisia and Egypt, we can advance that individuals involved in organizations were more likely to join the 2010-2011 protests and demonstrations than those not engaged, despite some differences in relation to the role of trade unions (Hypothesis 1).

\section{The role of informal groups}

Other studies show that the mobilization of resources for protests in repressive contexts frequently derives from informal networks and loosely structured social groups, producing dynamics closed to what Bayat has referred to as non-movements (Bayat, 2010). Indeed, under authoritarian conditions, places where informal groups meet, where political information becomes diffused, and where collective and shared feelings among activists can develop, are the streets, or the square.

As they have been studied in non-authoritarian contexts, informal groups are characterized by a latent, loose and unstable structure and a segmented and reticular network (Melucci, 1996).

Due to their flexible, adaptable, and contingent structural nature, informal networks can, therefore, become crucial in repressive contexts (Duboc, 2011). Indeed, political claims can be more easily channeled through informal groups of friends, acquaintances, neighbors, getting together in private houses, cafés, in the street. The hidden and latent structure of these groups not only enables to survive repression but also allows people 
to directly experience oppositional identities and cultural models and form circuits of solidarity (Melucci, 1996, p. 115).

Thanks to dense and close-knit interactions informal groups can mobilize primary solidarities, and convincing personal involvement and commitment in the context of rapidly shifting political opportunities. Primary solidarities may nurture the construction of alternative identities, based on the politicization of shared grievances pertaining to private life (Gould, 1991; Pfaff, 1996, p. 98). In small and midsize informal groups, where individuals have high levels of trust, loyalties to each other, and strong shared feelings of belonging, expectations of solidarity and participation are possible even under conditions of extreme risk (Gould, 1991). Friends and acquaintances may also enable the exchange of political information, political discussion, and political resources and the amount of political discussion occurring in an individual's social network correlates with his or her level of political participation (Klofstad, 2011).

Empirical evidence in the MENA region consistently portrays informal groups and ties as significant mobilizing structures in repressive contexts. As argued by Beinin and Vairel (2011, pp. 6-7), most social movements in the MENA region have historically relied on informal networks enabling practices and forms of resistance to bypass the authority. In Egypt, in the 1980s, activism moved to spaces such as those around literary production or journalistic circles (Duboc, 2011, 65 ff). Furthermore, workers' protests in Egypt between 2006 and 2009 did not rely on 'movement entrepreneurs' or preexisting organizations. With the exception of the support by several labor-oriented NGOs, workers' protests in Egypt mainly relied on irregular face-to-face meetings and mobile telephones, supported by family and neighborhood connections (Beinin, 2011, p. 183). According to Beinin and Vairel (2011), the 2011 protests in Egypt were indeed possible thanks to personal networks among workers, neighborhood ties, or ties built through workers' children attending the same schools. Clark (2004, pp. 169-170), when examining nadwas, that is Qur'anic study or discussion groups where groups of women gather together in homes to read and discuss passages from the Qur'an, highlights three mechanisms of mobilization occurring in such groups: first, they bring Islamist women in regular contact with non activists; second, they provide a micromobilization context in which cognitive liberation and collective attribution can occur; third, they provide the necessary structures of solidarity and interpersonal rewards.

As to Tunisia, woman workers were often organized through informal groups rather than formal membership to UGTT, partly due to the patriarchal attitudes and hierarchy of UGTT as well as to the fact that UGTT did not represent workers who worked informally, a status shared by many women workers (Debuysere, 2018).

Following the aforementioned arguments, and against our expectations in hypothesis 1 on the role of organizations, we expect that in contexts of repression, individuals who are part of informal groups - of friends, acquaintances, neighbors, workmates - are more likely to mobilize resources for protest engagement (hypothesis 2). In other words, in repressive contexts, recruitment into protest action is expected to be highly dependent on resources deriving from informal groups. 


\section{Methods}

\section{Data source of quantitative analysis}

The empirical study uses data collected in 2010-2011 at the individual level in Egypt and Tunisia, through the second wave of the Arab Barometer survey (Arab Barometer). The dataset contains detailed information on the anti-regime protests occurred in December 2010 in Tunisia, and in January 2011 in Egypt.

The Arab Barometer uses multi-stage area probability sampling to select respondents, with quota sampling employed in the final stage in several countries. ${ }^{4}$ The sample size in Egypt includes 1,144 individuals, and 1,187 individuals are part of the Tunisian sample. These samples represent a national probability sample of adults 18 years and older. Interviews were face-to-face in Arabic and were undertaken between 16 June and 3 July 2011, in Egypt, and between 30 September and 11 October 2011 in Tunisia.

\section{Dependent variable}

The dependent variable of the Egyptian sample considers whether individuals joined the protests against former president Hosni Mubarak between 25 January and 11 February 2011. The dependent variable for the Tunisian sample consists of whether individuals engaged in the protests against former president Zain Al-Abdeen Ben Ali between 17 December 2010 and 14 January 2011. Both of these variables are binary and 1 is assigned to individuals who participated in such protests.

\section{Independent variables}

Mobilizing structures. Formal organizational membership: To test hypothesis 1 advancing a link between formal membership in organizations and protests, we consider membership in the following types of organizations: a charitable society, a professional association/trade union, a youth/cultural/sport/organization, a family/tribal association (only for the Egyptian sample), a local development association.

Informal ties: To test hypothesis 2 on the mobilizing impact of informal groups, we consider whether any friends or acquaintances participated in the protests against former president Mubarak between 25 January and 11 February (for the Egyptian sample) and against former president Ben Ali between December and 14 January 2011 (for the Tunisian sample). ${ }^{5}$

\section{Control variables}

Our two hypotheses rely on theories emphasizing the role of intermediate social groups for protests advancing that individuals who are members of organizations and who have friends or acquaintances among protesters are more likely to join the protest. Next to the role of social groups, social movement scholars have also argued that framing processes and an opening political opportunity structure (POS) are crucial for the emergence of protests (cf. McAdam, McCarthy, \& Zald, 1996). Following this, we include a proxy for the framing dimension, testing the impact of individual perceptions of the current and future country's economic situation. These variables are aimed to capture the injustice component of collective action (Gamson, 2011). We also include attitudes towards authorities, a variable which aims to measure a POS-related dimension. Indeed, according to the political process 
model, protests are often challenging élites and authorities' status quo (Tilly, 1978; for more detailed measurement of the POS in the Egyptian case cf. Barrie \& Ketchley, 2018). Other control variables test the impact of several sociodemographic and socioeconomic individual characteristics which, according to classical models of political participation in Western countries, are drivers of protests, namely, respondents' sex, civil status, age, educational level attained, occupational status. Among political attitudes, we include political interest and political information. Finally, we add resources related to the use of the Internet, as well as religious behaviors, namely attending religious lessons in mosques or churches, attending Friday prayers, reading the Quran.

The Online Methodological Appendix shows the descriptive statistics of these variables by country (Table A1) and their coding.

\section{Data source of qualitative analysis}

The qualitative research in Egypt concerns two focus groups, conducted in Sayeda Zeinab (Cairo) and Mahalla al-Kubra (Nile Delta) between 2011 and 2015, involving 16 interviewees. The first focus group tackled seven members of Popular Committees, grassroots groups actively engaged in the 2011 protests which emerged during the initial stages of the 2011 protests in Egypt active as selfdefense groups, check-points and service-delivery (Hassan, 2015). The members involved were male and female unmarried young Egyptians (20-34 years old) with different political and economic backgrounds but mainly coming from middle and upper-middle class families. They were all living close to Berqet Fil, a small alley parallel to Port Said Street in the popular neighborhood of Sayeda Zeinab. Nine unionized male and female workers were part of the second focus group. They were all living in Mahalla al-Kubra and its outskirts. Two trade unionists and activists, Hamdi Hussein and Gamal Hassanin, acted as gatekeepers in order to select the workers involved in this focus group. In a preliminary stage, Hamdi and Gamal were part of the process for the composition and organization of this specific focus group.

The qualitative research in Tunisia relied, first, on eight semi-structured interviews conducted between February and May 2017 in the neighboring districts of Ben Arous, Medinat Jedida, and Yasminette, in the urban suburbs of Greater Tunis. This area, close to the mercantile port of Rades, is home to one of the most important manufacturing industries of the country, especially for textiles such as denim, mostly used to produce blue jeans. As reported in the 2014 INS census (Institute Nationale de Statistique [INS]), over $25 \%$ of the working population in the districts of Medinat Jedida, Yasminette and Ben Arous is employed in the textile-manufacturing sector, characterizing these districts as areas with some of the highest proportion of the working population employed in the textile industry when compared to the average of the country $(18,29 \%)$. INS statistics calculate temporary or precariat employees as employed workers. Most workers employed in the textile sector indeed work on temporary contracts, and often get dismissed and re-employed more times in the same year. Interviews were mostly conducted inside coffee shops or inside private homes, following a 'snowball- 
sampling' technique whereby participants would propose other participants. All interviewees were Tunisians between 25 and 36 years of age, with primary education level, sharing a similar working-class background. All of them had worked at different times in the denim factories of the districts of Ben Arous, Medinat Jedida, and Yasminette.

Second, evidence on Tunisia draws on extracts from 100 interviews to women. Interviews had been conducted within the frame of a study which tackled police violence against women during the protests started in December 2010. Interviews were undertaken between January and February 2011 in the Tunisian town of Kasserine (Zouhour and Nour) and in the village of Thala.

Details on the characteristic of the members of the focus groups in Egypt and on interviewees in Tunisia are reported in the Online Methodological Appendix.

\section{Findings}

Table 1 shows the multivariate analysis separately for Egypt (model 1) and for Tunisia (model 2).

Given space constraints, in the following discussion, we limit our interpretation to findings addressing our hypotheses. We integrate this analysis with the qualitative interpretation of data drawn from the focus groups in Egypt and the interviews in Tunisia.

\section{The role of popular committees for protests in Egypt}

With regard to the first hypothesis advancing a link between organizational membership and protests, results show that in Egypt, out of 5 different types of organizations, only membership in charity organizations increases individuals' probability to join protest in 2011 (cf. model 1 of Table 1). While charities do not often engage in political activities and are therefore free spaces capable to operate in repressive contexts, members of these organizations tend to act as political actors. The results of the quantitative analysis in Table 1 are integrated by the qualitative analysis which provides evidence for the impact of charities on protests throughout 2011. Indeed, from January 2011 onwards Popular Committees, rooted in the Islamic charity sector, have been crucial for the continuation of protests. Many members of Popular Committees were in fact supporters of the Muslim Brotherhood and of Salafi groups (El-Meehy, 2012). In particular, Popular Committees were often rooted within the pre-existing networks of Muslim Brotherhood charities, Private Voluntary Organizations (PVO), schools and hospitals. As the interviewee Mustafa confirmed, 'In Berqet Fil, many participants within the Popular Committees were involved in associations working with the elders or providing social services to the disabled'. ${ }^{6}$ Popular Committees were initially informal groups which acted as 'self-defense groups - heterogeneous in their tactics, organization, and efficacy - providing a critical response to the security vacuum' (Hassan, 2015, pp. 383-386). Indeed, in three days, after the first demonstration in Tahrir Square in Cairo on 25 January 2011, the police began to retreat or apparently disappear from the Egyptian streets. Following this, in a few hours, Popular Committees were quickly organized. 'Neighborhood watch brigades, typically led by 
Table 1. Correlates of engagement in protests; logit regression models (coefficients and standard errors in parenthesis).

\begin{tabular}{|c|c|c|c|c|}
\hline & \multirow{2}{*}{\multicolumn{2}{|c|}{$\frac{\text { (Model 1) }}{\text { Egypt }}$}} & \multirow{2}{*}{\multicolumn{2}{|c|}{$\begin{array}{c}\text { (Model 2) } \\
\text { Tunisia }\end{array}$}} \\
\hline & & & & \\
\hline & $\mathrm{b}$ & se & $\mathrm{b}$ & se \\
\hline \multicolumn{5}{|l|}{ Membership in formal organizations } \\
\hline Member of charity society & $1.370^{* *}$ & $(0.445)$ & 0.765 & $(0.690)$ \\
\hline Member of trade union/professional association & -0.830 & (0.449) & 0.860 & $(0.523)$ \\
\hline Member of youth/cultural/sport association & 0.149 & $(0.567)$ & 0.407 & $(0.532)$ \\
\hline Member of local development association & 1.000 & $(0.974)$ & 0.340 & $(0.926)$ \\
\hline Member of family/tribal association & -1.928 & $(1.426)$ & & \\
\hline \multicolumn{5}{|l|}{ Informal ties } \\
\hline $\begin{array}{l}\text { Any friends or acquaintances participate in the protests against former } \\
\text { president }\end{array}$ & $2.966^{* * *}$ & $(0.373)$ & $2.228^{* * *}$ & $(0.291)$ \\
\hline \multicolumn{5}{|l|}{ Control variables } \\
\hline Respondent's sex & $1.210^{*}$ & $(0.477)$ & $1.307^{* * *}$ & $(0.288)$ \\
\hline Age (range 18-85) & 0.003 & $(0.015)$ & $-0.038^{* *}$ & $(0.014)$ \\
\hline Being married & -0.241 & $(0.420)$ & -0.179 & $(0.317)$ \\
\hline Highest level of education attained & 0.085 & $(0.109)$ & $-0.213^{*}$ & $(0.099)$ \\
\hline \multicolumn{5}{|l|}{ Occupation (ref: being student) } \\
\hline Works (no better specified) & - & - & 0.145 & $(0.583)$ \\
\hline Retired & 0.124 & $(1.114)$ & -0.308 & $(0.765)$ \\
\hline Housewife & 0.984 & $(0.932)$ & -0.666 & $(0.587)$ \\
\hline Unemployed & 0.466 & $(0.917)$ & -0.147 & $(0.364)$ \\
\hline Employer/director & 0.974 & (1.097) & 1.076 & $(0.632)$ \\
\hline Professional (lawyer, accountant, teacher, doctor, etc.) & $2.280^{*}$ & (0.899) & 0.161 & $(0.662)$ \\
\hline Manual laborer & 0.868 & $(1.024)$ & -0.065 & $(0.474)$ \\
\hline Agricultural worker/owner of a farm & 1.506 & $(0.955)$ & -0.693 & $(1.193)$ \\
\hline Member of the armed forces/public security & 2.601 & $(2.345)$ & & \\
\hline Owner of a shop/grocery store & 1.483 & $(0.942)$ & -0.123 & $(0.575)$ \\
\hline Government employee & 1.221 & $(0.877)$ & $1.102^{*}$ & $(0.518)$ \\
\hline Private sector employee & 1.090 & $(0.875)$ & -0.723 & $(0.476)$ \\
\hline Craftsperson & 1.638 & $(0.935)$ & & \\
\hline Very interested or interested in politics & -0.152 & $(0.493)$ & -0.188 & $(0.281)$ \\
\hline Follows political news very often or often & 0.678 & $(0.580)$ & $0.770^{*}$ & $(0.303)$ \\
\hline Reading the Quran always or most of the time & -0.010 & $(0.380)$ & 0.406 & $(0.251)$ \\
\hline Attends religious lessons in mosques or churches & -0.201 & $(0.348)$ & 0.709 & $(0.383)$ \\
\hline Attends Friday prayers & -0.125 & $(0.429)$ & -0.403 & $(0.290)$ \\
\hline Uses internet at least once a week & 0.520 & $(0.340)$ & $0.601^{*}$ & $(0.283)$ \\
\hline Evaluation of current country's economic situation & 0.001 & $(0.200)$ & $0.414^{* *}$ & $(0.153)$ \\
\hline Evaluation of future country's economic situation & -0.005 & $(0.158)$ & 0.051 & $(0.127)$ \\
\hline Supports government's decision & 0.192 & $(0.155)$ & 0.102 & $(0.130)$ \\
\hline Constant & $-7.286^{* * *}$ & $(1.325)$ & $-4.060^{* * *}$ & $(0.893)$ \\
\hline$\|$ & -191.52 & & -279.02 & \\
\hline $\mathrm{N}$ & 1,025 & & 852 & \\
\hline
\end{tabular}

Source: Arab Barometer wave 2, 2010-2011.

Significance levels: ${ }^{*} p<.05{ }^{* *} p<.01{ }^{* * *} p<.001$.

young men, sprang up to fill the security void as reports of criminal violence mounted' (El-Meehy, 2012).

As the interviewee Mustafa ${ }^{7}$ added, the Popular Committees were

spontaneous networks built-up on the perfect knowledge of each neighborhood of the Muslim Brotherhood supporters and their capacity to identify any minimum risk. [...] Many of the participants in the Popular Committees in my neighborhood were supporters of the Muslim Brotherhood and were already sharing reciprocal relationships of trust or were active in their Private Voluntary Organizations. ${ }^{8}$ 
Mustafa ${ }^{9}$ added that many Popular Committees of his neighborhood were directly forged from the organizational structures of the local branches of the Muslim Brotherhood. 'The Popular Committees have been put in place thanks to the organizational structure of the Muslim Brotherhood and their specific knowledge of the district'. In this sense, Popular Committees have exhibited important continuities with Islamist activism', comprised mostly of 'upwardly mobile, educated, middle-class professionals' (El-Meehy, 2017).

Popular Committees participants played a crucial role in promoting individuals' active engagement in politics, including both institutional and non-institutional politics like protests (El-Meehy, 2012). According to El-Meehy (2012), in some districts the Committees continued to gather in the spring and summer of 2011 to discuss the main problems of the neighborhood: cleaning streets, fixing water fountains to improve living conditions in the area and painting buildings but also gradually turned their attention to politics, evolving toward active citizenship (El-Meehy, 2012). The Committee's participants were involved in the electoral campaign for the constitutional amendments in the March 2011 referendum, and especially young, students or unemployed members of Popular Committees were the first to take part during the continual waves of protest mobilization and the electoral campaigns. Some of them appeared to be motivated by more conscious revolutionary and secular intentions: 'We wanted a new Constitution. For this reason, we distributed flyers asking to the people to vote No'. ${ }^{10}$ Others were motivated by a nationalist, populist and genuine sense of belonging: 'We agreed with the decision of the Muslim Brotherhood to support the call of the army not to make major changes to the then existing Constitution'. ${ }^{11}$

Ard al-Lewa's Committee mobilized around the establishment of a park, school and a hospital on fourteen feddans of vacant land owned by the Ministry of Religious Endowments (Awqaf) in the neighborhood. Next door, the committee in Imbaba organized effective nonpayment campaigns for public services the state had failed to provide, such as garbage collection, while Nahia's Committee constructed an on/off ramp to connect the neighborhood to the ring road. ${ }^{12}$

Those who did take part in Sayeda Zeinab's Popular Committees were active in their own neighborhood during the major episodes of mass mobilization, which accompanied the spread of new waves of unrest: the Fridays of Anger, during the attacks on the State Security (Amn el-Dawla) on 9 April 2011 and the Baloon Theater clashes on 30 June 2011. Some members of the Sayeda Zeinab's Popular Committees extended their mobilization out of the neighborhood. For instance, Ahmed, Midu and Khaled took part in their first demonstration on the occasion of the Mohammed Mahmud Street clashes of November 2011. 'This was the first time we went to Tahrir Square. We witnessed the violence of plain clothes policemen, infiltrated within the protests'. ${ }^{13}$ 'At that stage, some of the people of my area went for the first time to Tahrir Square holding Egyptian flags, motivated by their nationalist sense of belonging' ${ }^{14}$

\section{ETUF and independent trade unions' role for protests in Egypt}

Model 1 of Table 1 further shows that, in Egypt, other organizations, also those more closely related to political action, such as trade unions and youth 
organizations, did not act as structures of resources mobilization for the 2011 protests. This confirms the lack of engagement by the official trade unions, EFTU, in the 2011 Egyptian protests. Indeed, the traditional trade unions, controlled by Mubarak's regime did not call for labor protests in 2011 even if workers were clearly ready for mass mobilization. ${ }^{15}$ Many workers were initially organized in more spontaneous oppositional groups and workers' committees acting at the local level had no 'institutional mechanism to compel the ETUF to join the popular movement against Mubarak' (Beinin, 2011, p. 107). Spontaneous workers' groups found an institutional form only after the protests broke out, through the creation, on 30 January 2011, of the Egyptian Federation of Independent Trade Unions (EFITU), formed thanks to the Center for Trade Union and Workers Services (CTUWS) coordinator, Kamal Abbas, and the Union of Real Estate Tax Authority Workers (RETAU) president, Kamal Abu Eita, along with smaller unions of teachers, health professionals and retiree associations. In April 2013, the second federation of independent unions was established, the Egyptian Democratic Labour Council (EDLC), convening with 149 unions represented. ${ }^{16}$ The pro-regime ETUF continued to support the state institutions despite the Tahrir Square demonstrations encouraged the workers' groups to mobilize and communicate (Tripp, 2013, p. 160). Early 2011, a nationwide teachers' strike involved half a million workers demanding the cleansing (tathir) of public institutions of the remnants of the old regime (Hanieh, 2013, p. 169) and in February 2011 in Egypt, 489 strikes occurred. The workers involved in our second focus group in Egypt, members of independent trade unions, confirmed their early participation in the 2011 protests in Mahalla alKubra. Many of them had already been involved in the previous anti-regime mobilizations and strikes. The participants who were unionized workers demanded better labor conditions and new investments in the textile industries. 'We were among the hundreds of young people of the revolution gathering in Shon Square in Mahalla al-Kubra'. 17 'We were asking for a better life and human working conditions'. ${ }^{18}$ 'We participated during the first protests after an already longlasting struggle to overcome the rooted crisis of the Egyptian cotton industry'. ${ }^{19}$ But this interviewee had some previous experience: 'We have been used for years to go downtown Cairo during mass demonstrations and strikes or close to Mubarak residency in Qasr al-Qobba to demonstrate against his neo-liberal labor policies'. ${ }^{20}$

\section{The role of UGTT and spontaneous workers' groups for protests in Tunisia}

The role of trade unions in the Tunisian case is different than the one found for Egypt. Model 2 shows no significant effect of trade union membership on the anti-regime protests erupted in December 2010 in Tunisia. ${ }^{21}$ However, the qualitative analysis is clearer in emphasizing the role of UGTT, and its interweaving with more spontaneous groups of workers. In Tunisia, protests were joined by government employees as well as students and unemployed, the two latter making up the largest percentage of protesters. As shown by the qualitative research conducted in Tunisia, testimonies from workers taking part in protests between December 17 and January 142010 indicate a strong reliance on national union mobilization. The local branch of the major Tunisian trade union, Union Générale Tunisienne du Travail (UGTT) in Ben Arous organized 
a demonstration in front of its headquarters in the last days of December, to which most members attended. 'The demonstration calls had been repeated and encouraged by members of the unions, but we attended because we were aware of what was happening in the country. ${ }^{22}$ Local chapters of the UGTT were crucial for the eruption of protests in Ben Arous. Here, groups of workers and unemployed were especially active in the protests despite their membership to the UGTT was loosely defined due to the presence of many workers with precarious employment and on a temporary contract. The line between workers and unemployed was therefore blurred in Ben Arous due to the fact that most workers were employed on monthly contracts and no real distinction emerged between workers and unemployed. The organization of workers as a 'group' solidified because of the call to protest raised by formal organizations of which not all were actually members of.

I (recall) the moment I saw the unions' communicate on the phone of a friend of mine. My uncle was sitting in the same café, some tables aside (...), when he read the message he swore that if the UGTT had called for a picket, then also those without a job like me, should have joined on the day. ${ }^{23}$

It was also through informal ties that individuals mobilized as family members, friends, and even neighbors would be encouraged to join protests. 'In Yasminette there was not the notion of workers and unemployed, we were all one, the young people of Yasmiette'. ${ }^{24}$ These groups were supported both by the structure and encouragement provided by the local union branches, and by the informal networks present in the community. 'On the day of the strike we were given banners and hats, I still have that hat, as it reminds me of the first day I shouted openly to a policemen'. ${ }^{25}$ The key for mobilization in Tunisia was provided by the support of local workers' organizations being integrated by informal ties existing among friends and family members, groups related to either the workplace or through houses, cafés, the street. Therefore, some groups formed and members recognized themselves as part of a 'group' only during and after the protests. Indeed, groups were both pre-existing structures of mobilization, and a result of the political climate emerged out of the December 2010 protests.

Evidence coming from the eight semi-structured interviews with individuals who had participated in the 2011 protests in Tunisia suggests that the level of participation in the protests was higher when protests and strikes were called by formal organizations. Nonetheless, this does not contradict the high degree of spontaneity in the ways in which protesters both joined and performed protest in December 2010 and January 2011 in Ben Arous. As a participant put it: 'We would go to demonstrations organized by the local unions in Ben Arous and Medinat Jedida, but when it came to confronting the police, only the youth from the quartier was in the streets' ${ }^{26}$

Such relation - between spontaneous and organized action - can be further examined by considering the role of football fan clubs. Indeed, many young people living in Ben Arous and Yasminette are members of Club Africain's unregulated and outlawed ultras groups, yet having an organizational structure and internal hierarchy capable of managing donation-based funds. 'We've been having problems with the police forever. When we went to the streets we just did what we do when we leave the stadium and the police is there'. ${ }^{27}$ The flexibility created by the existence of loose memberships to fan 
groups was critical for workers unions when the first demonstrations erupted in Ben Arous and Yasminette in December 2010.

What we needed to confront the police present at the protests in Yasminette was just to get the guys of the Club African down with us and we would have a demonstration. You would see Club African flags waved by people wearing a UGTT union hat ${ }^{28}$

Consequently, affiliation to a workers' union or to a football fan group in Ben Arous is not a matter of rigid membership. The fact that such groups facilitated the participation to protests cannot ignore the fact that more loose and spontaneous groups eventually formed and took up the task to initiate and coordinate protest action.

After demonstrations or pickets, we split into the same groups we were when we went to the café (...). The cafès of Ben Arous were the places where we met after and before all protests, these were the places we would go and find other people to join the marches. ${ }^{29}$

The presence of both formal groups and of informal networks is thus testament of the overall mixed nature of protesters' groups, as many young people who would not usually be part of unions or football fans groups ended up marching with them and clashing with the police in January 2011 in Ben Arous and Yasminette. This nonetheless, informal networks grew strong and aware of their own existence only after protests were called by workers' unions.

\section{The role of other groups}

Model 2 in Table 1 further shows that no other organizational membership was significant for the eruption of protests in Tunisia. This result, however, is also due to the limited amount of types of organizations considered in the quantitative analysis. In fact, women organizations were also active in big cities and especially in Tunis where the political elite, including a high share of women, had managed to forge an opposition to Ben Ali and Bourguiba regimes. Indeed, in addition to the Tunisian Association of Democratic Women (ATFD), many women were active in political parties and associations as well as in the UGTT, despite not occupying leadership roles. An interview with Amal Dhafouli, a 34 years old activist in Sidi Bouzid, argues that

I am independent but I collaborate a lot with the UGTT and other civil society organizations. At each sit-in or gathering, the UGTT supports us and helps us to open the doors of dialogue with the authorities. But even before the revolution and until today, I have never had to deal with women trade unionists in Sidi Bouzid or Tunis. Despite this, women were during the revolution and until today one of the drivers of social movements in the regions.

Female journalists and bloggers played a key role in the 2011 protests. An important example is Lina Ben Meheni, a renown blogger, Nobel nominee, who ensured the coverage of the protest events for several weeks in many languages (Chennaoui \& Baraket, 2011).

Overall, considering the results both for Tunisia and for Egypt, the impact of engagement in formal organizations is limited. Therefore, hypothesis 1 is only partly met. In contrast, for both Egypt and Tunisia, results of the quantitative analysis in Table 
1 and the qualitative studies confirm the crucial impact of informal ties, as already discussed, thus supporting hypothesis 2 .

More importantly, however, the integration of the quantitative and the qualitative analysis remarks the need to consider the interconnections between spontaneous groups and more stable organizations as, in a repressive context, they overlap, switch from one form to another, and transform themselves faster than they would do in democratic contexts.

\section{Conclusions: between spontaneity and organization}

This study has investigated the role of intermediate structures of mobilization in repressive contexts, trying to understand whether the significant effect of groups for the mobilization of resources for protests in democratic contexts differs under authoritarian regimes. To do this, the article has integrated the insights of a quantitative analysis with those of a qualitative one. Results suggest that organizations in repressive contexts become mobilizing structures by largely overlapping with informal ties. In particular, protests erupted in December 2010 in Tunisia and in January 2011 in Egypt were coordinated by organizations which often overlapped or emerged from informal ties and closed relationships built every day by neighbors, friends, relatives, and peers. Protests in repressive contexts, therefore, develop in spaces characterized by both spontaneity and organization. An understanding of formal engagement needs to be integrated with an understanding of informal ties which pervaded the Tunisian and Egyptian societies at the time of the uprisings. Our study, therefore, supports a nuanced vision of the role of organizations for protests in repressive contexts. Indeed, organizations have a flexible form whereby, as exemplified by the Tunisian case, membership is not so strict, and organizations can, at times, incorporate claims by un-organized members. Organizations have also a dynamic form as they are capable to react, and easily adapt to a changing context. The characteristics of groups change fast during the time of political turmoil in repressive contexts. Workers' spontaneous and informal groups in Egypt turned into more stable organizations through processes of institutionalization, as reflected by the legalization of EFITU. Popular Committees developed mostly from members' informal ties built through prior affiliations to the Muslim Brotherhood and to Salafi groups. In Tunisia, organizations such as UGTT ignited protests in the initial phase, but informal ties of workers were crucial to widen engagement by workers during the diffusion process.

Protests in 2011 were therefore well-grounded on mobilizing structures capable to survive in the interstices of an authoritarian context, namely, small groups of friends and acquaintances integrating, overlapping with, changing into or deriving from formal, stable and more organized groups capable to survive the repressive context. This interconnection suggests that neither spontaneity nor coordination and organization prevailed during the Arab uprisings, and that a nuanced vision joining the two different group forms - organizations and informal groups - and their changing dynamics need to be considered. 


\section{Notes}

1. For security reasons, we prefer to keep the names of the individuals involved anonymous and provide fictitious names. These focus groups were part of a broader research by Giuseppe Acconcia (2018) conducted between 2011 and 2015 on Popular Committees and Independent Trade Unions in Egypt.

2. The eight semi-structured interviews were part of a broader research by David Leone Suber (2017) and the extracts of the 100 interviews were part of a broader project in which Henda Chennaoui collaborated (Chennaoui \& Baraket, 2011).

3. For a definition of the process of mobilization implying the passage from passive individuals to active participants in political life cf. Tilly (1978, p. 69).

4. The sampling design included stratification (by governorate and urban-rural) and clustering. Interviews were distributed proportionally to population size. For further methodological details see the Arab Barometer Project, http://www.arabbarometer.org/ .

5. For a discussion on the direction of the relationship between organizational membership and protest engagement and between informal ties and protest engagement cf. the Online Methodological Appendix.

6. Case 1, Interviewee 7, Cairo.

7. Case 1, Interviewee 1, Cairo.

8. Case 1, Interviewee 1, Cairo.

9. Case 1, Interviewee 7, Cairo.

10. Case 1, Interviewees 1, 2, 3, 6 and 7, Cairo.

11. Case 1, Interviewees 4 and 5, Cairo.

12. Ibid.

13. Case 1, Interviewees 2, 3 and 4, Cairo.

14. Case 1, Interviewees 5 and 6, Cairo.

15. Looking at the correlation between specific categories of workers who joined protests in Egypt, results in model 1 of Table 1 show that professionals were significantly more likely to protest than students. Indeed, as mentioned, professionals had been largely active in organizations such as Kifaya in Egypt during the years prior to 2011.

16. http://www.madamasr.com/sections/politics/whatever-happened-egypts-independentunions. Last time accessed on 10 May 2016.

17. Case 2, Interviewees 3, 4 and 9, Mahalla al-Kubra.

18. Case 2, Interviewee 5, Mahalla al-Kubra.

19. Case 2, Interviewees 1, 2 and 6, Mahalla al-Kubra.

20. Case 2, Interviewees 3 and 7, Mahalla al-Kubra.

21. The effect is positive and significant at $\mathrm{p}=0.11$; therefore, it is not shown in Table 1 .

22. Case 3, Interviewee 1, Ben Arous.

23. Case 3, Interviewee 3, Ben Arous.

24. Case 3, Interviewee 7, Yasminette.

25. Case 3, Interviewee 4, Medinat Jedida.

26. Case 3, Interviewee 8, Yasminette.

27. Case 3, Interviewee 7, Yasminette.

28. Case 3, Interviewee 7 and 8, Yasminette.

29. Case 3, Interviewee 2, Ben Arous.

\section{Disclosure statement}

No potential conflict of interest was reported by the authors. 


\section{Notes on contributors}

Katia Pilati is Assistant Professor at the Department of Sociology and Social Research (DSRS) at the University of Trento, Italy. Before joining DSRS, she was a Marie Curie fellow at the University of Geneva, and a FRS-FNRS research fellow at the Université Libre de Bruxelles. Her research interests include political participation, social movements, social networks, immigration. Her works appeared, inter-alia, in Acta Sociologica, European Journal of Political Science, Journal of Ethnic and Migration Studies, Mobilization. She is the author of three books (Armando 2010; Palgrave Macmillan 2016; Il Mulino 2018).

Giuseppe Acconcia is a researcher focusing on the Middle East, Post-Doc University of Padova, Visiting Scholar University of California (UCLA - Center for Near Eastern Studies), Teaching Assistant at Bocconi, Lecturer at Cattolica University in Milan (ASERI). He holds a PhD at the University of London (Goldsmiths). He is the author of The Great Iran (Exorma, 2016), Egypt. Military Democracy (Exorma, 2014) and The Egyptian Spring (Infinito, 2012). He published in MERIP, Carnegie Endowment for International Peace (Sada), Policy Press and Palgrave.

David Leone Suber is a researcher focusing on the Middle East and North Africa. He holds an MA in Comparative Middle East politics from Tübingen University and the American University of Cairo (2017). As a full-time contributor to the Brush \& Bow graphic-journalism collective, he currently reports about the issue of refugee's return to Syria from the Syrian-Lebanese border. His works appear on Rosa Luxemburg Foundation Index (2018), Refugee Review (2017), Al Araby al Jedeed, Al Jadaliyya, Middle East Monitor and Salon Syria.

Henda Chennaoui is an independent journalist and scholar specialized in human rights and social movements. Since 2013 she has been working with Nawaat, an independent collective blog. She writes, inter-alia, on injustice, environmental problems, corruption. Currently, she is the moderator of the Middle East Forum in Tunisia of Open Democracy and she is pursuing a master of research in Sociology at Ibn Charaf University, Tunis.

\section{ORCID}

Katia Pilati (D) http://orcid.org/0000-0002-9234-6230

\section{References}

Acconcia, G. (2018). The uprisings in Egypt: Popular committees and independent trade unions (PhD thesis). London: Goldsmiths College (University of London).

Ahrne, G., \& Brunsson, N. (2011). Organization outside organizations: The significance of partial organization. Organization, 18(1), 83-104.

Almeida, P. D. (2003). Opportunity organizations and threat-induced contention: Protest waves in authoritarian settings. American Journal of Sociology, 109(2), 345-400.

Arab Barometer, Wave II. (2010-2011). Retrieved from http://www.arabbarometer.org/waves/ arab-barometer-wave-ii/

Barrie, C., \& Ketchley, N. (2018). Opportunity without organization: Labor mobilization in Egypt after the 25th January revolution. Mobilization: An International Quarterly, 23(2), 181-202.

Bayat, A. (2010). Life as politics - How ordinary people change the Middle East. Amsterdam: Amsterdam University Press.

Beck, C. J. (2014). Reflections on the revolutionary wave in 2011. Theory and Society, 43(2), 197-223.

Beinin, J. (2011). A workers' social movemetn on the margins of the global neoliberal order, Egypt 2004-2009. In J. Beinin, \& F. Vairel (Eds.) Social movements, mobilization, and contestation in the Middle East and North Africa (pp. 181-201). Stanford: Stanford University Press. 
Beinin, J., \& Vairel, F. (Eds.). (2011). Social movements, mobilization, and contestation in the Middle East and North Africa. Stanford: Stanford University Press.

Brockett, C. D. (1991). The structure of political opportunities and peasant mobilization in Central America. Comparative Politics, 23(3), 253-274.

Carey, S. (2009). Protest, repression and political regimes: An empirical analysis of Latin America and Sub-Saharan Africa. New York: Routledge.

Chennaoui, H., \& Baraket, S. (2011). Les Abandonnées de la Révolution - Étude des violences faites aux femmes à Thala et Kasserine lors de la répression de l'insurrection de décembre 2010-janvier 2011. Switzerland and Uganda: Isis-WICCE Exchange Institute Alumni.

Clark, J. (2004). Islamist women in Yemen: Informal nodes of activism. In Q. Wiktorowitz (Ed.), Islamic activism: A social movement theory approach (pp. 164-184). Bloomington: Indiana University Press.

Davenport, C., Hank, J., \& Mueller, C. (2005). Repression and mobilization. Minneapolis: University of Minnesota Press.

Davis, G. F., McAdam, D., Scott, W. R. E., \& Zald, M. N. (2005). Social movements and organization theory. Cambridge: Cambridge University Press.

Debuysere, L. (2018). Between feminism and unionism: The struggle for socio-economic dignity of working-class women in pre- and post-uprising Tunisia. Review of African Political Economy, 45(155), 25-43.

Diani, M. (2015). The cement of civil society. Studying networks in localities. New York, NY: Cambridge University Press.

Dorsey, J. M. (2012). Pitched battles: The role of ultra soccer fans in the Arab spring. Mobilization: An International Journal, 17(4), 411-418.

Duboc, M. (2011). Egyptian leftist intellectuals' activism from the margins: Overcoming the mobilization/demobilization dichotomy. In J. Beinin \& F. Vairel (Eds.), Social movements, mobilization, and contestation in the Middle East and North Africa (pp. 61-79). Stanford: Stanford University Press.

El-Meehy, A. (2012). Egypt's popular committees from moments of madness to NGO dilemmas. Middle East Research and Information Project. 42 (265) website edition, Last time accessed Winter 2016.

El-Meehy, A. 2017. Governance from below. Comparing local experiments in Egypt and Syria after the uprisings, report Arab politics beyond the uprisings. The Century Foundation. Retrieved February 10, 2017, from https://tcf.org/content/report/governancefrom-below/

Gamson, W. (2011). Arab spring, Israeli summer, and the process of cognitive liberation. Swiss Political Science Review, 17(4), 463-468.

Goldstone, J., \& Tilly, C. (2001). Threat (and opportunity): Popular action and state response in the dynamic of contentious action. In R. Aminzade, J. Goldstone, D. McAdam, E. Perry, W. Sewell, \& S. Tarrow (Eds.), Silence and voice in the study of contentious politics (pp. 179-194). Cambridge: Cambridge University Press.

Gould, R. (1991). Multiple networks and mobilization in the Paris Commune, 1871. American Sociological Review, 56(6), 716-729.

Hanieh, A. (2013). Lineages of revolt, issues of contemporary capitalism in the Middle East. Chicago, IL: Haymarket Books.

Hassan, H. (2015). Extraordinary politics of ordinary people: Explaining the micro dynamics of popular committees in revolutionary Cairo. International Sociology, 30(4), 383-400.

Institute Nationale de Statistique. (2016). Ben Arous: A travers le Recensement Général de la Population et de l'Habitat 2014. Tunis. Retrieved from http://www.ins.nat.tn/fr/publication/ ben-arous-\%C3\%A0-travers-le-recensement-g\%C3\%A9n\%C3\%A9ral-de-la-population-et-de-1 $\%$ E2\%80\%99habitat-2014

Kadivar, M. A. (2013). Alliances and perception profiles in the Iranian reform movement, 1997 to 2005. American Sociological Review, 78(6), 1063-1086.

Klofstad, C. C. (2011). Civic talk: Peers, politics, and the future of democracy. Philadelphia, PA: Temple University Press. 
Kriesi, H.-P. (1996). The organizational structure of new social movements in a political context. In D. McAdam, J. D. McCarthy, \& M. N. Zald (Eds.), Comparative perspectives on social movements: Political opportunities, mobilizing structures, and cultural framings (pp. 152-184). Cambridge: Cambridge University Press.

McAdam, D., McCarthy, J. D., \& Zald, M. N. (Eds.). (1996). Comparative perspectives on social movements: Political opportunities, mobilizing structures, and cultural framings. New York, NY: Cambridge University Press.

McCarthy, J. D., \& Zald, M. N. (1977). Resource mobilization and social movements: A partial theory. American Journal of Sociology, 82, 1212-1241.

McVeigh, R., \& Sikkink, D. (2001). God, politics, and protest: religious beliefs and the legitimization of contentious tactics. Social Forces, 4, 1425-1458.

Melucci, A. (1996). Challenging codes - Collective action in the information age. New York, NY: Cambridge University Press.

Moghadam, V., \& Gheytanchi, E. (2010). Political opportunities and strategic choices: Comparing feminist campaigns in Morocco and Iran. Mobilization, 15(3), 267-288.

Pfaff, S. (1996). Collective identity and informal groups in revolutionary mobilization: East Germany in 1989. Social Forces, 75(1), 91-118.

Pilati, K. (2011). Political context, organizational engagement, and protest in African countries. Mobilization An International Journal, 16(3), 351-368.

Pilati, K. (2016). Do organizational structures matter for protests in non-democratic African countries? In E. Y. Alimi, A. Sela, \& M. Sznajder (Eds.), Contention, regimes, and transition Middle East and North Africa protest in comparative perspective (pp. 46-72)). Oxford: Oxford University Press.

Suber, D. L. (2017). Failing readmission: If sending migrants back won't work. A case study of Italy and Tunisia. Berlin: Rosa Luxemburg Stiftung North Africa Office Publication Index.

Tchaïcha, D. J., \& Arfaoui, K. (2017). The Tunisian women's rights movement: From nascent activism to influential power-broking. London: Routledge.

Tekeli, S. (Ed.). (1995). Women in modern Turkish society: A reader. London: Zed Books.

Tilly, C. (1978). From mobilization to revolution. Reading, Mass.: Addison-Wesley.

Trejo, G. (2012). Popular movements in autocracies: Religion, repression, and indigenous collective action in Mexico. New York, NY: Cambridge University Press.

Tripp, C. (2013). The power and the people, paths of resistance in the Middle East. New York, NY: Cambridge University Press.

Verba, S., Schlozman, K., \& Brady, H. (1995). Voice and equality: Civic voluntarism in american politics. Cambridge, MA: Harvard University Press.

Wickham, C. R. (2002). Mobilizing Islam: Religion, activism, and political change in Egypt. New York: Columbia University Press.

Wiktorowicz, Q. (Ed.). (2004). Islamic activism - A social movement theory approach. Bloomington: Indiana University Press. 